Çukurova Üniversitesi Mühendislik Mimarlık Fakültesi Dergisi, 34(3), ss. 235-246, Eylül 2019

Çukurova University Journal of the Faculty of Engineering and Architecture, 34(3), pp. 235-246, September 2019

\title{
İçme Sularında Bulunan E. Coli Bakterilerinin Görüntü İşleme Yöntemleriyle Tespiti
}

\author{
Evren DEĞİRMENCİ*1, Ahmet Hilmi KALOĞLU' ${ }^{*}$, Emre GÜVEN \\ Samet DURAK ${ }^{1}$, Hakan ORBUK ${ }^{1}$
}

Mersin Üniversitesi, Mühendislik Fakültesi, Elektrik-Elektronik Mühendisliği Bölümü, Mersin

Geliş tarihi: 16.03.2019 Kabul tarihi: 30.09 .2019

$\ddot{O} z$

Yaşamsal faaliyetlerdeki önemi düşünüldüğünde, kullanılacak suyun temiz olması, içerisinde hastalık yapıcı bakterileri bulundurmaması gerekmektedir. Suyun içinde bulunan hastalık yapıcı bakterilerden birisi, Enterobacteriaceae familyasına ait Escherichia coli (E. coli) bakterisidir. E. coli bakterilerinin tespiti için günümüzde yaygın olarak kullanılan yöntemde su numunesinden damıtılan bakteri endo agar besi yerine ekilmekte ve bakterilerin metabolik faaliyetleri sonucunda besi yerinin renginde oluşan değişim çıplak gözle incelenmektedir. Bu renk değişiminin insan gözü ile görülebilecek düzeye gelmesi yaklaşık olarak $22 \pm 2$ saat sürmektedir. Bu çalışmada $E$. coli bakterilerinin daha kısa sürede ve pratik şekilde tespit etmeyi sağlayacak bir düzenek ve görüntü işleme yöntemleri temelli yeni bir analiz yöntemi önerilmiştir. Önerilen teknik, farklı ekim yöntemleri ile test edilmiştir. Elde edilen bulgular, önerilen yöntemle bakteri tespitinin 8-10 saat aralığında yapılabileceğini göstermiştir.

Anahtar Kelimeler: Escherichia coli, E. coli, Görüntü işleme, Bakteriyolojik inceleme

\section{Determination of $E$. Coli Bacteria in Drinking Waters Using Image Processing Techniques}

\begin{abstract}
Considering the importance on vital activities, the water to be used should be clean and not contain diseasecausing bacteria. One of the pathogenic bacteria found in water is the bacterium Escherichia coli (E. coli) belonging to the family Enterobacteriaceae. In the commonly used method for the detection of $E$. coli bacteria, the bacteria distilled from the water sample are planted on endo agar medium and the change in the color of the medium as a result of the metabolic activities of the bacteria is examined by the naked eye. This color change can be recognizable with the human eye in approximately $22 \pm 2$ hours. In this study, a hardware and a new analysis method which is based on image processing techniques to enable the detection of $E$. coli bacteria in a shorter time and in a practical way is proposed. The proposed technique is tested with different sowing methods. Results have shown that the detection of bacteria can be done within 8-10 hours with the proposed method.
\end{abstract}

Keywords: Escherichia coli, E. coli, Image processing, Bacteriological examination

*Sorumlu yazar (Corresponding author): Evren DEĞİRMENCİ, evrendegirmenci@mersin.edu.tr 


\section{GíRiș}

İnsanların, hayatlarını sürdürebilmeleri için en önemli ihtiyaçlarından birisi sudur. $\mathrm{Su}$, vücudumuzun 1S1 dengesinin sağlanması, vücuda alınan besinlerin taşınması, sindirilmesi ve temel besin öğelerinin kana karışması gibi metabolik faaliyetlerde önemli bir yere sahiptir [1].

Vücudumuzun neredeyse tüm reaksiyonlarında aktif rol oynaması göz önünde bulundurulduğunda, kullandığımız suyun temiz olması, içerisinde hastalı yapıcı bakterileri bulundurmaması gerekmektedir. Türk Standartları Enstitüsü'nün TS 266 içme ve kullanma suları standardında (2005) suların sahip olması gereken kalite kriterleri belirtilmiştir. Burada da bildirildiği üzere, sularda dikkat edilmesi gereken en önemli kriterlerden birisi mikrobiyolojik parametrelerdir [2].

Dünya Sağlık Örgütü'nün (WHO) 2013-2020 yılları için hazırlanan "Su kalitesi ve Sağlık Stratejisi" başlıklı raporuna göre, 2011 yılında dünya genelinde 58 ülkede toplam 589.854 adet su kaynaklı enfeksiyon vakası bildirilmiştir [3].

Suyun içinde bulunan hastalık yapıcı bakterilerden birisi, Enterobacteriaceae familyasına ait Avusturyal1 Doktor Thedor von Escherich tarafından keşfedilen Escherichia coli (E. coli) bakterisidir. E. coli, aslında canlıların kalın bağırsaklarında yaşayan bakteri türlerinden birisidir. Ancak, canlıların dışkıları ile kaynak sularına bulaşıp su kirliliğine de yol açmakta ve çevre koşullarına bağlı olarak 4-12 hafta kadar hayatta kalabilmektedir [4].

E. coli sebep olduğu hastalıklara göre farklı patotiplere ayrılmaktadır. Başlica patotipleri Enterotoksijen E. coli (ETEC), Enteroinvazif E. coli (EIEC), Enteropatojenik E. coli (EPEC), Enterohemorajik E. coli (EHEC), Enteroaggregatif E. coli (EAEC), Diffusely Adherent E. coli (DAEC) ve Üropatojenik E. coli (UPEC)' dir [5].

Her patotip farklı hastalık semptomlarına sebep olmaktadır. Bunların en ünlüsü sayılan hemolitik üremik hastalık tablosu (HÜS) etmeni O157:H7 adlı serotip, kanlı ishale ve ölüme yol açabilmektedir. WHO, 22 Temmuz 2011 tarihli raporunda 16 Avrupa Ülkesi ve Kuzey Amerika için 4.075 adet $E$. coli bulaşması ve HÜS vakası ile 50 ölüm vakası bildirmiştir [6].

Sebep olduğu hastalıklar göz önünde bulundurulduğunda $E$. coli bakterilerinin hızlı ve etkili tespiti, salgın hastalıkların önüne geçilmesi ve ölümlerin azaltılması açısından ciddi önem arz etmektedir. Bu sebepten içme ve kullanma sularının güvenilir olmasını sağlayacak her türlü tedbir Türkiye ve Dünya için artı bir değer olmaktadır [7].

Bakterilerin tespiti genellikle besi yeri kullanılarak yapılmaktadır [8]. Besi yerleri mikroorganizmaların gelişmesi için uygun hale getirilmiş ortamlardır. Mikroorganizmaların metabolik faaliyetlerini gerçekleştirmek için ihtiyaç duydukları bileşenleri içerirler. $\mathrm{Bu}$ besi yerlerinin kullanımı yoluyla, mikroorganizmaların geliştirilmesi, izolasyonu, tanımlanması, sayımı ve duyarlılık testlerinin yapılmasıyla, klinik örneklerin incelenmesi, gıda, su ve çevre kontrolleri gibi farklı birçok amaca ulaşılabilir. Bakterilerin tespitinde kullanılan besi yerlerine eklenen çeşitli indikatörler ve kimyasal maddeler yardımıyla, üreyen kolonilerin aldıkları renge göre mikroorganizmaları tanımlamak mümkün olmaktadır. Örneğin bir su numunesi besi yeri kullanılarak analiz edilmek istendiğinde, öncelikle su numunesindeki bakteri membran filtre yardımıyla izole edilmekte, ardından da besi yerine sürülerek veya damlatılarak uygun ortam koşullarında belirli süre bekletildikten sonra çeşitli analizlere tabi tutulmaktadır. Ayrıca bakterilerin, manyetik nanopartiküller yardımıyla su, yeşil yapraklı bitkiler veya et ve süt ürünleri gibi gıda maddelerinden izole edilip daha sonra çeşitli özelliklere sahip besi yerleri kullanılarak analiz edildiği çalışmalar literatürde mevcuttur [9-11].

E. coli bakterilerinin tespit edilmesi için çok çeşitli yöntemler geliştirilmiştir. Bu yöntemlerin arasında bakterilerin ışıma yapan kimyasallar ile etiketlenerek veya mangan katkılı çinko gibi çeşitli mineraller kullanıldıktan sonra mikroskop altında incelendiği çalışmalar mevcuttur [12-16]. Ayrıca E. coli bakteri tespitinin mikroskop kullanılmadan 
büyütmesiz olarak yapılması da mümkündür. Bunun için doğrudan insan gözü ile besi yerindeki E. coli bakterileri için karakteristik olan bazı değişimlerin incelenmesi mümkün olduğu gibi hiperspekral görüntüleme, termal görüntüleme veya optik görüntüleme gibi çeşitli görüntüleme teknikleri kullanılarak bakteri varlığının tespiti de imkan dahilindedir [16-20]. Ancak bu yöntemler genellikle yüksek maliyetli veya özel donanımlar gerektirmekte ve bu yüzden de günlük hayatta kullanımları sınırlı kalmaktadır.

E. coli bakterilerinin tespitinde en s1k kullanılan yöntem E. coli'nin endo agar katı besi yerine ekilmesi ve tepkimenin izlenmesidir. E. coli bakterileri besi yeri içinde bulunan laktozu, asit ve aldehit oluşturarak metabolize ederler [21]. Oluşan aldehit, fuksin-sülfit bileşiğindeki fuksini serbest bırakır ve böylece koloni rengi kırmızı olur. E. coli ve diğer bazı koliform grup üyelerinde bu reaksiyon çok kuvvetli olarak gerçekleşir ve kolonideki fuksin kristalleri koloni renginin metalik parlak yeşil (metalik röfle) olmasını sağlar. E. coli gelişimi için en uygun sıcaklık $37{ }^{\circ} \mathrm{C}$ olduğu için inkübasyon çoğunlukla $37{ }^{\circ} \mathrm{C}$ 'de ve aerobik koşulda yapılır. Metalik röfle oluşumunun gözle görünür hale gelmesi yaklaşık $22 \pm 2$ saat süresinde olmaktadır [22-24]. Düşük maliyetli, dolayısıyla yaygın kullanılan bir yöntem olmasına karşın bakteri tespit süresinin bu denli uzun olması, kirlenmiş suların tüketiciye ulaştıktan ve hatta kullanıldıktan sonra E. coli'nin tespit edilmesi gibi ciddi problemleri beraberinde getirmektedir.

$\mathrm{Bu}$ çalışmada su numunelerinin analizinde kullanılabilecek, suya bulaşmış E. Coli bakterilerinin katı besi yerinde meydana getirdiği renk değişimini görüntü işleme teknikleri kullanarak daha hızlı şekilde tespit etmek amaçlanmıştır. $\mathrm{Bu}$ amaçla donanımsal bir düzenek kurulmuş ve incelenecek numune besi yerine ekildikten sonra besi yeri tasarlanan donanım içerisine yerleştirilmiştir. Klasik yöntemlerde gözle izlenen süreç, 24 saat boyunca besi yerinin fotoğrafı çekilerek ve görüntü işleme teknikleriyle analiz edilerek incelenmiştir.

\section{MATERYAL VE YÖNTEM}

\subsection{Besi Yerlerinin Hazırlanması ve Bakteri Ekimi}

Çalışmada E. coli bakterilerinin tespiti için endo agar katı besi yeri kullanılmıştır. Çalışmada kullanılan besi yerleri Mersin Üniversitesi Çevre Mühendisliği Bölümü laboratuvarında, laboratuvarda çalışan araştırmacılar tarafindan hazırlanmıştır. $\mathrm{Bu}$ kapsamda $1000 \mathrm{ml}$ distile suya eklenen 39 gr endo agar besi yeri otoklavda $121{ }^{\circ} \mathrm{C}$ 'de 15 dakika sterilize edilmiş, ardından $50{ }^{\circ} \mathrm{C}$ 'ye soğutulup petri kutularına $12,5 \mathrm{ml}$ olarak dökülmüş ve soğutulmuştur. Hazırlanan besi yerleri hazırlandıkları ilk anda saydam ve soluk pembe renktedir. Besi yeri zamanla havada bulunan oksijenle tepkimeye girerek koyulaşmaktadır. Besi yerinin yaklaşık bir hafta boyunca havayla temas etmesi sonucunda koyu kırmızı renkler yeşil renge doğru dönmektedir. E. coli bakterilerinin tespit edilebilmesi için metalik röfle denilen parlak yeşil renge ihtiyaç olması sebebiyle bu besi yerlerinin çok uzun bir süre havayla temas ettirilmeden kullanılması, deneylerin sağlıklı sonuç vermesi açısından önemlidir. Gerçek hayattaki su analizlerinde besi yerinin taze olarak hazırlanacağ1 göz önünde bulundurularak bu çalışmadaki besi yerleri deneyler öncesi yenilenmiştir.

Yapılacak deneyler için iki farklı bakteri ekim türü kullanılmıştır. İlk etapta bakteriler besi yerinin yüzeyine dağıtılarak yaygı şeklinde ekilmiş ve bakteri yoğunluğunun metalik röfle oluşumu üzerindeki etkisi gözlemlenmiştir.

Diğer ekim türü olarak ise besi yerinin herhangi bir noktasına, yaygı yöntemine göre daha az miktarda olacak şekilde bakteri ekilmiş ve metalik röfle oluşumu gözlemlenmiştir.

Şekil 1'de çalışma kapsamında kullanılmış olan yaygı ekim yapılmış bir besi yerinin 24 saat bekledikten sonra gözle görülür derecede metalik röfle oluştuktan sonraki örnek görüntüsü verilmiştir. 


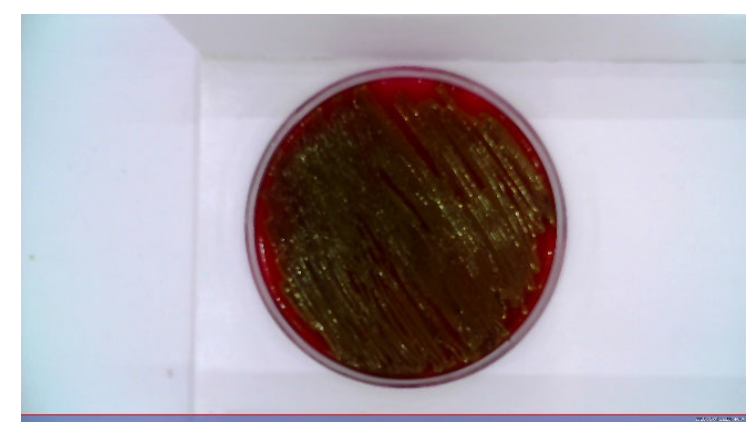

Şekil 1. Çalı̧̧mada kullanılan, bakteri ekilmiş bir besi yerinin 24 saat sonundaki görüntüsü

\subsection{Besi Yerini Görüntülemek için Tasarlanan Düzenek ve Görüntülerin Eldesi}

Besi yerinin görüntülenmesi için kullanılacak olan, özel tasarım fotoğraf stüdyosu olarak da adlandırılabilecek dikdörtgenler prizması şeklinde bir düzenek tasarlanmış, çekimlerin dış 1 şık koşullarından etkilenmemesi için ışık geçirmeyen malzeme kullanılarak imal edilmiştir. Düzeneğin üst kısmına, görüntü çekimi amaciyla 1920x1080 (full HD) çözünürlüğe sahip bir kamera yerleştirilmiştir. Düzeneğin yüksekliği kameranın odaklanma durumu da göz önünde bulundurularak $20 \mathrm{~cm}$ olarak tasarlanmıştır. Besi yerinin rahatça yerleştirilebilmesi için düzeneğin ön tarafina bir çekmece konumlandırılmıştır. Bu sayede düzeneğe yerleştirilen besi yerinin her deney için aynı noktaya yerleştirilmesi ve yapılan bütün deneylerde aynı kamera görüş alanı ile görüntüler toplanması sağlanmıştır. Düzeneğin tavan kısmına ise görüntü toplama sırasında ihtiyaç duyulan ortam aydınlatmasını sağlayabilmek için RGB şerit led yerleştirilmiştir. Her ne kadar bu çalışmada çekimler beyaz renk aydınlatma altında yapılmış olsa da, ilerleyen çalışmalarda farklı aydınlatma koşulları altında denemeler yapılabileceği düşünülerek RGB led tercih edilmiştir.

Bakteri tespit işleminin su deposu vb. gibi yerlerde yapılacağı ve bu yerlerde her zaman uygun sıcaklık koşullarını sağlayacak cihazların bulunamayacağ göz önüne alınarak deneylerin $37^{\circ} \mathrm{C}$ 'de değil de oda sicaklığında yapılmasına karar verilmiştir. $\mathrm{Bu}$ durumun elde edilen bulgulara etkisi, ilgili başlık altında tartışılmıştır. Sistemin kontrol edilmesini sağlayan elektronik devrenin ortam koşullarına etki etmemesi ve ayrıca inkübatör içerisinde yapılması muhtemel çalışmalarda inkübatör içerisindeki sıcak ve nemli ortam koşullarından etkilenmemesi için ikinci bir kutu tasarlanmış, güç kaynağı, mikrodenetleyici kartı ve hazırlanan kontrol devresi bu kutuya yerleştirilerek besi yeri yerleştirilecek olan kutunun dişında tutulmuştur. Tasarlanan görüntüleme sistemi donanımının son hali Şekil 2'de gösterilmiş̧ir.

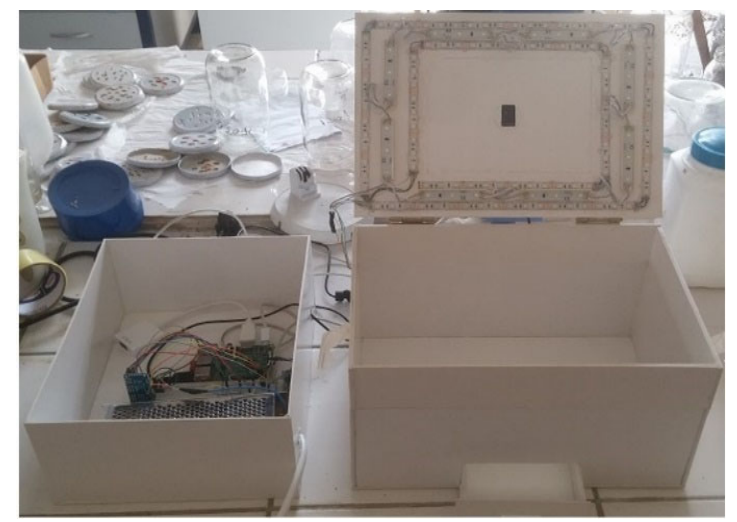

Şekil 2. Tasarlanan görüntüleme sistemi

Besi yerinin görüntülenmesi için kullanılan kameranın ve ortam aydınlatması için kullanılan RGB şerit led'in kontrolü için Raspberry Pi 3 mikro-denetleyici kartı kullanılmıştır. Mikrodenetleyici kartının istenen görüntü ayarlarıyla besi yerinin fotoğraflarını çekip tarih ve saat etiketleriyle hafiza kartı birimine kaydetmesini sağlayan yazılım, bu çalışma kapsamında hazırlanmıştır. $\mathrm{Bu}$ yazılımın akış diyagramı Şekil 3'te verilmiştir.

Fotoğraf çekimi sırasında ortamın aydınlatılması için düzenekte kullanılan RGB şerit led $12 \mathrm{~V}$ ile çalışmaktadır. Hem RGB led'lerin hem de mikrodenetleyici kartının güç ihtiyacının karşılanması için 12V 10A güç kaynağı kullanılmıştır.

Led aydınlatmanın deney süresince açık kalması ortam sıcaklığını az da olsa etkileyebileceği için yalnızca çekimler sırasında, kamerayla beraber açılıp geri kalan süreçte kapalı tutulmasının daha yararlı olacağı değerlendirilmiştir. Bunun için led aydınlatmanın RGB kanalları bir mosfet yardımıyla mikro-denetleyici kartı üzerinden anahtarlanmıştır. 


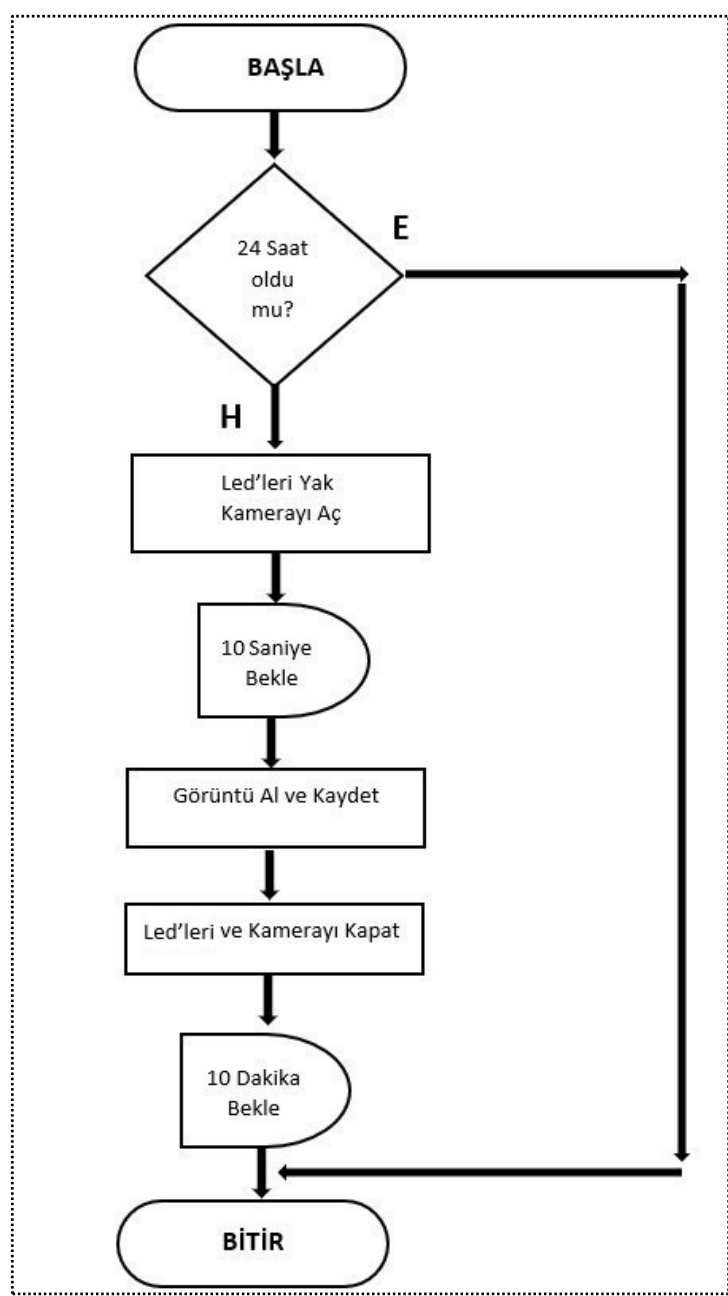

Şekil 3. Mikrodenetleyici kartı kontrolü için hazırlanan algoritmaya ait akış diyagramı

Tasarlanan anahtarlama devresi Şekil 4'te gösterilmiştir. Tasarlanan devre gerçeklenerek sisteme entegre edilmiştir. Led'lerin ve kameranın açılması sırasında kameranın 1 şı ve odak ayarlaması yapacağı, bunun da görüntüler arasında parlaklık ve netlik farkı yaratabileceği göz önünde bulundurularak çekimler, ledlerin enerjilenmesinin ardından 10 sn geciktirilerek yapılmıştır.

Tüm sistem hazırlandıktan sonra, bakteri ekimi yapılan besi yeri sistem içine yerleştirilmiş ve görüntü toplanmasına geçilmiştir. Görüntüler her bir besi yeri için 24 saat boyunca ve her 10 dakikada bir görüntü olacak şekilde çekilmiştir. Çekilen görüntülerin isimleri, çekildiği tarih ve saat olacak şekilde programlanmıştır.

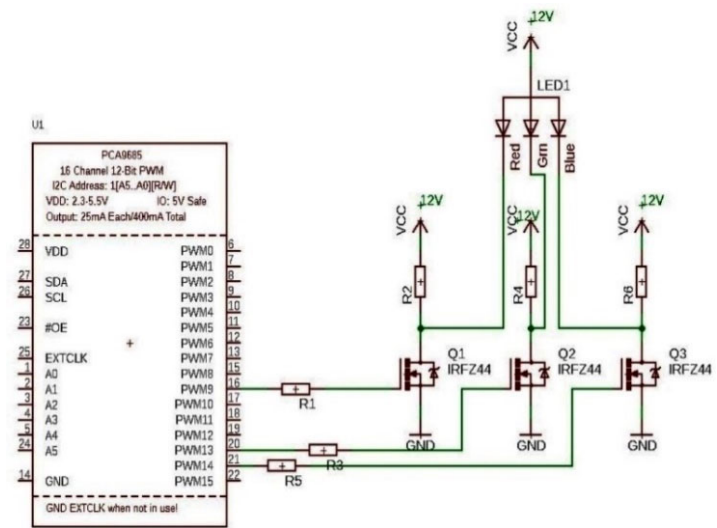

Şekil 4. Tasarlanan anahtarlama devresi

\subsection{Görüntülerin İșlenmesi}

Tasarlanan sistem ile toplanan görüntüler analiz edilmek için öncelikle hafıza kartından bilgisayara aktarılmıştır. Çekilen fotoğraflar incelendiğinde, besi yerinin dişında kalan alanların görüntü işleme yoluyla yapılacak analizler üzerinde olumsuz etkiler doğurabileceği değerlendirilmiştir; bu yüzden besi yerinin konumunun fotoğraf görüntülerinde belirlenmesine karar verilmiştir. Belirlenmek istenen kısım dairesel bir yapıya sahip olduğundan, görüntüler üzerinde Dairesel Hough Dönüşümü (CHT) işlemi uygulanmıştır [25]. Dairesel Hough Dönüşümü ile Eşitlik (1)'de verilen genel çember denklemi kullanılarak görüntülerdeki dairesel nesnelerin belirlenmesi mümkündür [26]:

$r^{2}=(x-a)^{2}+(y-b)^{2}$

Burada a ve b noktaları çemberin merkez koordinatları, $\mathrm{x}$ ve y çember üzerindeki herhangi bir noktanın koordinatları, $\mathrm{r}$ ise yarıçap değeridir.

CHT işlemi uygulanırken Şekil 5'te de gösterildiği gibi görüntü üzerindeki çemberlerin sınırlarındaki her bir piksel için, bu pikseli merkez kabul eden ve bu çember ile aynı yarıçap değerine sahip yeni çemberler çizilir. Çizilen tüm bu çemberlerin kesişim noktalarının en fazla olduğu yer ise tespit 
edilmek istenen çemberin merkez koordinatına karşılık gelmektedir. Yarıçapın bilinmediği durumlarda ise yarıçap için bir aralık belirlenir ve bu aralıktaki her değer için bu işlem merkez belirlenene kadar tekrarlanır. $\mathrm{Bu}$ çalışmada, kullanılan beherler standart ölçüde olduğundan, yarıçap bilgisi girilerek dönüşüm koşturulmuştur.

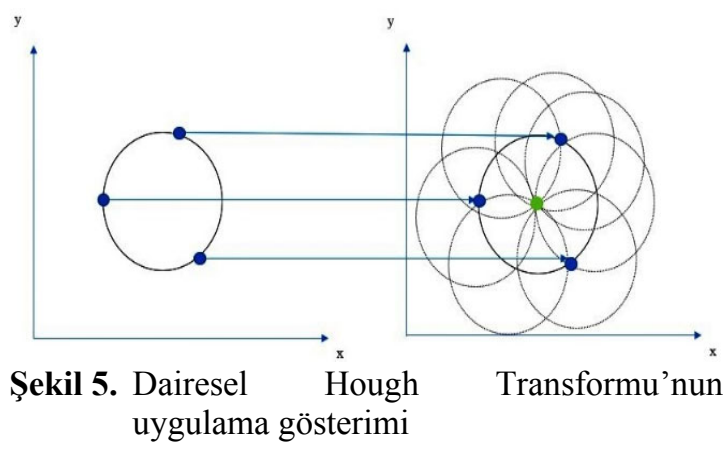

Çalışmada, çekilen her bir fotoğraf için, CHT yöntemi kullanılarak belirlenen ve fotoğraftaki beherin konumuna karşılık gelen koordinatlar yardımıyla birer görüntü maskesi hazırlanmıştır. $\mathrm{Bu}$ sayısal maskenin elde edilen görüntüler üzerine uygulanması ile hem besi yerinin dışında kalan alanların sonuçlara etki etmesi engellenmiş, hem de RGB şerit led'lerden kaynaklanan yansımaların ortadan kaldırılması sağlanmıştır.

Görüntüler maskelenerek analiz edilmeye uygun hâle getirildikten sonra metalik röfle tespiti işlemlerine geçilmiştir. Bunun için, öncelikle metalik röfle renginin piksel değerlerinin bilinmesi gerekmektedir. Yapılan test çekimleri üzerinde analizler yapılarak, metalik röfle rengi için piksel değeri belirleme çalışmaları yapılmıştır. $\mathrm{Bu}$ işlem birçok görüntüde tekrarlanmış ve metalik röfle piksel değeri için bir aralık belirlenmiștir. Aynı zamanda bu değer aralığının görüntünün kırmızı, yeşil ve mavi katmanındaki karşılığı da tespit edilmiştir. Daha sonra, kaydedilen görüntülerin kırmızı, yeşil ve mavi katmanları Matlab ${ }^{\circledR}$ ortamında birbirinden ayrılmış, daha önce elde edilmiş olan metalik röfle piksel değer aralığının ilgili kanaldaki karşılığı kullanılarak bir oylama (voting) işlemi [27] yapılmıştır. Çalışmadaki bu işlemin matematiksel karşılığ verilmiştir:

$$
\mathrm{v}=\left\{\begin{array}{ccc} 
& & 130 \leq \mathrm{f}(\mathrm{x}, \mathrm{y})_{\text {krrmız }} \leq 220 \\
\mathrm{v}+1 & \text { eğer } & 35 \leq \mathrm{f}(\mathrm{x}, \mathrm{y})_{\text {yeșil }} \leq 120 \\
& & 0 \leq \mathrm{f}(\mathrm{x}, \mathrm{y})_{\text {mavi }} \leq 65 \\
\mathrm{v} & \text { eğer } & \text { diğer durumlarda }
\end{array}\right.
$$

Burada $f(x, y)_{l}$ kaydedilmiş görüntünün ilgilenilen $l$ katmanıdır (l: RGB katmanları; Kırmızı, Yeşil, Mavi) ve tüm katmanlardaki değerin belirlenen metalik röfle renk aralığına düşmesi durumunda $v$ sayacı bir arttırılmaktadır. Bu işlem kullanılarak metalik röfle piksel sayısının peş peşe çekilen görüntülerdeki değişimine bağll, bir başka deyişle zamana bağlı değişimini gösteren grafik hazırlanarak incelenmiştir. Metalik röfle renginin oluşumu, besi yerine ekilen bakterilerin metabolik faaliyetleri sonucunda gerçekleştiğinden, metalik röfle olan piksel sayısının düzenli olarak artması beklenmektedir. Ancak, hazırlanan grafik incelendiğinde, bazı görüntülerde zaman ilerlerken metalik röfle olan piksel sayılarının azaldığ görülmektedir. Görüntüler üzerinde yapılan incelemelerden sonra bu sorunun sebebinin besi yerinin yüzeyinde oluşan yansımalar ve gölgelenmeler olduğu tespit edilmiştir. Bunların ortadan kaldırılması için görüntüler üzerinde RGB normalizasyonu işlemi yapılmıştır [28]. RGB normalizasyonu, her renk değerinin Eşitlik (3)'te verilen işlemler yardımıyla yeniden elde edilmesiyle yapılan ve görüntüler üzerindeki yansımalar ve gölgelenmelerin bastırılmasını sağlayan bir yöntemdir.

$\mathrm{R}^{\prime}=\frac{\mathrm{R}}{\mathrm{R}+\mathrm{B}+\mathrm{G}}, \mathrm{G}^{\prime}=\frac{\mathrm{G}}{\mathrm{R}+\mathrm{G}+\mathrm{B}}, \mathrm{B}^{\prime}=\frac{\mathrm{B}}{\mathrm{R}+\mathrm{G}+\mathrm{B}}$

RGB normalizasyonu yapıldıktan sonra elde edilen görüntüler üzerinde metalik röfle piksel sayısı tespit işlemi gerçekleştirilmiştir. Bu işlem yoluyla metalik röfleye karşılık gelen piksellerin konumları da elde edilebilmiştir. Başka çalışmalarda işe yarayabileceği düşünülerek, yalnızca metalik röfle renginde olan piksellerin kendi konumlarında bulunduğu bir görüntü de oluşturulmuştur. $\mathrm{Bu}$ görüntünün metalik röflenin yeşile yakın bir renk olması sebebiyle yeşil renkte gösteriminin daha uygun olacağı düşünülmüştür. $\mathrm{Bu}$ amaçla, elde edilen metalik röfle piksellerinin bulunduğu görüntü, oluşturulacak görüntünün yeşil katmanı olacak şekilde konumlandırılmıștır. Kırmızı ve 
mavi kanallar için ise sıfır dolgulama (zero padding) işlemi yapılmış ve böylece elde edilen görüntünün yalnızca yeşil bileşenin olması sağlanmıştır.

\section{BULGULAR VE TARTIŞMA}

Besi yerinin zamanla renk değişim miktarının görülmesi ve bu durumun bakteri ekildikten sonra yapılacak analizlere etkisinin incelenebilmesi için bakteri ekimi yapılmamış bir besi yeri, 24 saat boyunca 10'ar dakika arayla görüntülenerek kontrol grubu verileri olarak toplanmıştır. 4'er saat arayla bu görüntülerden seçilen örnekler, Şekil 6'da verilmiştir.

Şekil 6'da verilen kontrol grubu görüntüleri incelendiğinde, bakteri ekilmemiş besi yeri üzerinde metalik röfle oluşmadığ 1,24 saat süresinde az miktarda renk koyulaşması meydana geldiği görülmektedir.

Çalışmada, hem ekim işleminin besi yerinin yüzeyine yaygı şeklinde yapılmasının, hem de besi yerinin herhangi bir noktasına yaygı ekime göre daha az olacak şekilde yapılmasının sonuçlara etkisi incelenmiştir. Yaygı ekim yöntemiyle hazırlanan besi yerinden 4'er saat arayla çekilen ham görüntülerden birer tanesi Şekil 7'de verilmiştir.

Yayg1 ekime kıyasla daha az miktarda olacak şekilde, besi yerinin sol üst köşesine damlatma yoluyla bakteri ekilmiş besi yerinden çekilen ham görüntülerden 4'er saat arayla birer tanesi ise Şekil 8'de verilmiştir.

Bu noktada şunu belirtmek önemlidir: Şekil 7 ve Şekil 8 (d)'den itibaren fotoğraflarda görülen motif değişimleri, bakterinin girdiği reaksiyon sonucu oluşan değişimlerdir. Ancak, özellikle Şekil 8 (d) ve 8 (e)'de verilen fotoğraflarda hala gözle net olarak görülebilen metalik röfle oluşumu söz konusu değildir Metalik röfle oluşumu, özellikle 20. saate ulaşıldığında çekilen görüntülerde gözle net görülebilir hale gelmektedir ve bu durum da Şekil 7 ve 8'deki (f) ve (g) görüntülerinde görülebilmektedir.

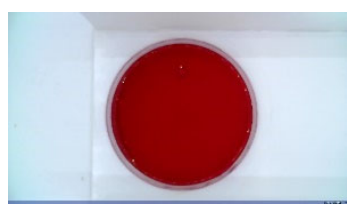

(a)

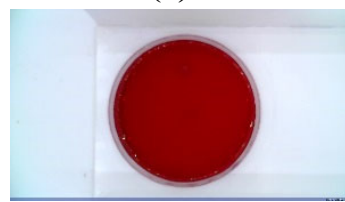

(c)

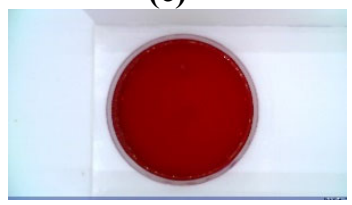

(e)

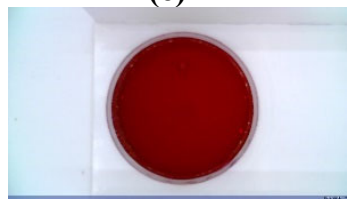

(g)

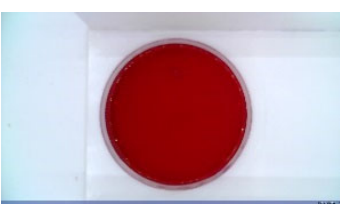

(b)

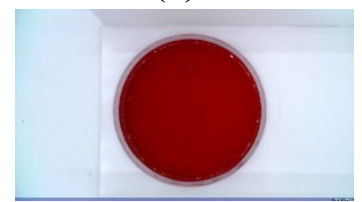

(d)

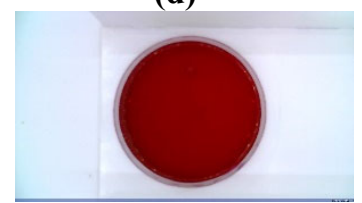

(f)
Şekil 6. Bakteri ekimi yapılmamış besi yerinin: (a) başlangıç görüntüsü, (b) 4. saatteki görüntüsü, (c) 8 . saatteki görüntüsü, (d) 12. saatteki görüntüsü, (e) 16. saatteki görüntüsü, (f) 20. saatteki görüntüsü ve (g) 24. saatteki görüntüsü

Çekilen görüntülerin analizini kolaylaştırmak ve sonuçların doğruluğunu arttırmak maksadıyla, CHT yöntemiyle hazırlanan görüntü maskesinin tek başına görüntüsü Şekil 9 (a)'da, bu maskenin çekilen besi yeri fotoğrafina uygulanması sonucu elde edilen maskelenmiş besi yeri görüntüsü örneği ise Şekil 9 (b)'de verilmiştir.

$\mathrm{Bu}$ aşamaların ardından görüntülerin analizine geçilmiştir. Yöntem kısmında da anlatıldığı şekilde, maskelenmiş görüntülerdeki metalik röfle renginde olan pikseller tespit edilmiş ve bu piksellerin sayısının zamana göre değişimleri ardışık görüntüler incelenerek tespit edilmiştir. Öncelikle bakteri oluşumunun incelenmesi için kontrol verisi olması amacıyla, bakteri ekilmemiş besi yerindeki metalik röfle rengindeki piksellerin zamana göre 


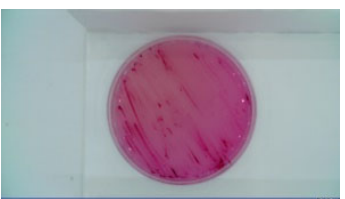

(a)

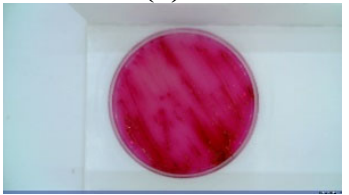

(c)

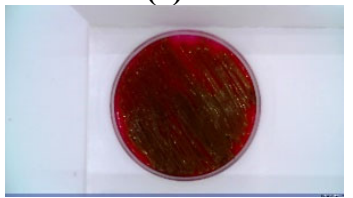

(e)

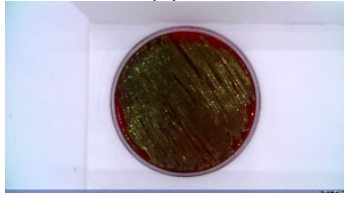

(g)

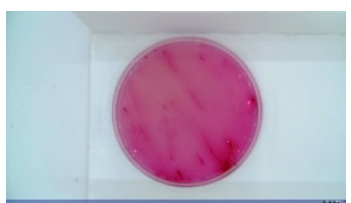

(b)

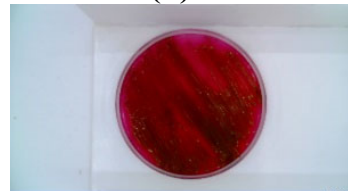

(d)

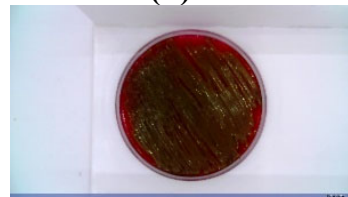

(f)
Şekil 7. Yaygı ekim yöntemiyle bakteri ekilmiş besi yerinin: (a) başlangıç görüntüsü, (b) 4. Saatteki görüntüsü, (c) 8. Saatteki görüntüsü, (d) 12. Saatteki görüntüsü, (e) 16. Saatteki görüntüsü, (f) 20 . Saatteki görüntüsü, (g) 24. Saatteki görüntüsü

değişimi incelenmiştir (Şekil 10). Maskelenmiş besi yeri görüntüsünün yaklaşık 1 milyon piksele sahip olduğu göz önünde bulundurulduğunda, bakteri ekilmiş sonuçlara kıyasla çok az denebilecek sayıda, yaklaşı 100 adet (\% 0,1 oranında) pikselin metalik röfle rengine sahip olduğu ve bu sayının 24 saat boyunca yaklaşık olarak sabit kaldığ görülmüştür. $\mathrm{Bu}$ pikseller tüm alana dağılmış durumda olduğundan gözle seçilmesi mümkün değildir. Yaklaşık 100 pikselde bu değerin görülmesinin kullanılan kamera sensörlerinin kalitesiyle alakalı olabileceği değerlendirilmiştir. Piksel sayısının 24 saatin sonuna doğru hafif artmasının ise besi yerinin zamanla çok yavaş şekilde eskimesi ve yüzeyinin oksijenle ve ortam koşullarıyla tepkimeye girmesi olarak düşünülmüștür. Ancak 24 saat civarındaki sürelerin çalışmanın hedeflediği bakteri tespit süresinin çok üstünde olması sebebiyle, bu sürelerde meydana gelen metalik röfle rengi piksel sayısı artışının elde edilen tespit süresi sonuçlarına etkisinin olmayacağını söylemek mümkündür.

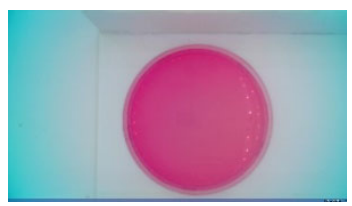

(a)

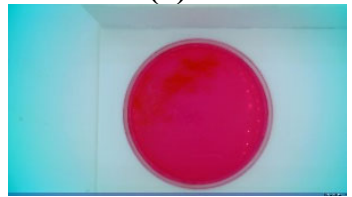

(c)

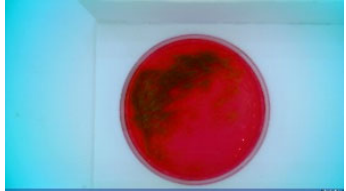

(e)

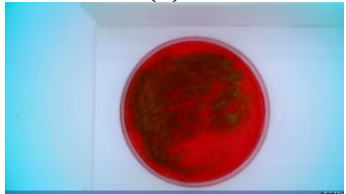

(g)

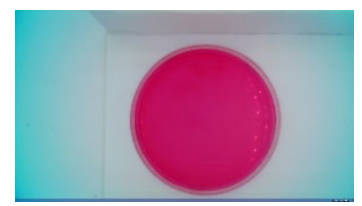

(b)

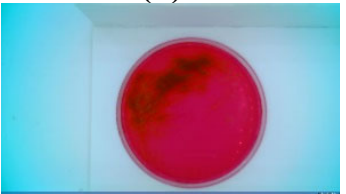

(d)

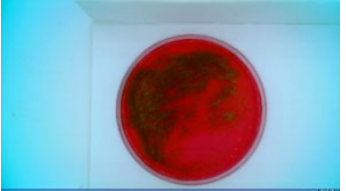

(f)
Şekil 8. Sol üst köşesine ekim yapılmış besi yerinin: (a) ilk görüntüsü, (b) 4. Saatteki görüntüsü, (c) 8. Saatteki görüntüsü, (d) 12. Saatteki görüntüsü, (e) 16. Saatteki görüntüsü, (f) 20. Saatteki görüntüsü, (g) 24. Saatteki görüntüsü

Şekil 11'de yayg1 ekim yöntemi kullanılarak hazırlanan besi yerindeki metalik röfle rengindeki piksel sayısının 24 saat boyunca değişimi grafik halinde sunulmuştur. Şekil 11'de verilen grafik incelendiğinde, önerilen yöntem ile metalik röfle oluşumunun 8-9 saat aralığında tespit edilmeye başlandığı görülmektedir. Ancak, önemli olan nokta şudur ki; 9. saatte bu oluşum hala gözle görülebilir düzeyde değildir. 9. saatteki maskelenmiş görüntü Şekil 12 (a)'da verilmektedir. Klasik, çıplak gözle incelemeli yöntemlerde bakteri ekilmiş besi yeri 24 saat süreyle bekletilmekte ve daha sonra incelenmektedir. 24 saatin sonunda $E$. coli bakterisi 
kaynaklı metalik röfle oluşumu çıplak gözle rahat şekilde görülebildiği maskelenmiş görüntü Şekil 12 (b)'de verilmiştir.

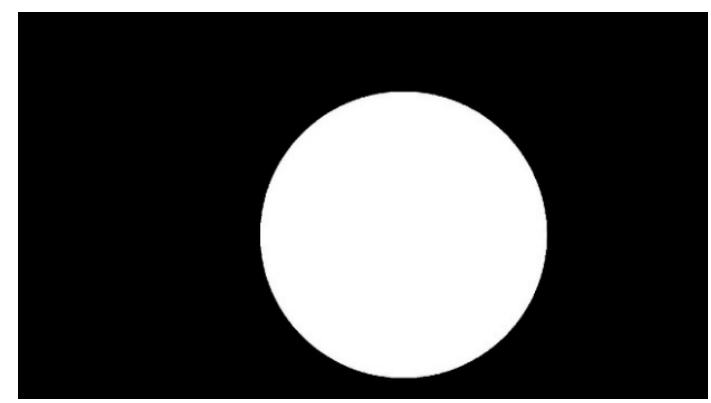

(a)

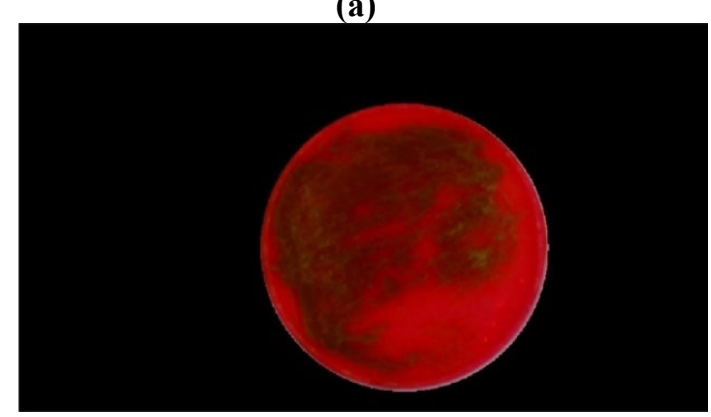

(b)

Şekil 9. (a) CHT yöntemiyle hazırlanmıs görüntü maskesi, (b) Maskelenmiş besi yeri görüntüsü

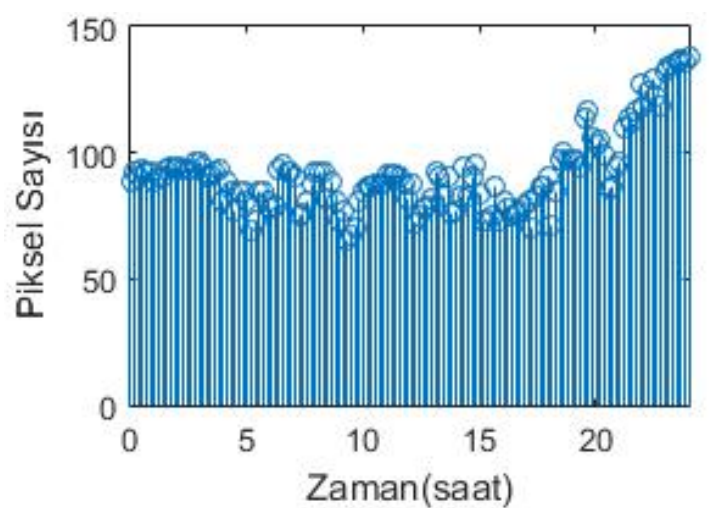

Şekil 10. Bakteri ekilmemiş besi yeri için metalik röfle rengindeki piksel sayısının zamana göre değişimi

Besi yerinin sol üst tarafına damlatma yoluyla bakteri ekimi yapılan numunede metalik röfle rengindeki piksel sayısının zamana göre değişimini gösteren grafik, Şekil 13'te verilmiștir. Grafik incelendiğinde, besi yerine tek noktadan ekim yapılması durumunda da bakteri kaynaklı metalik röfle oluşumunun 10. saatten itibaren tespit

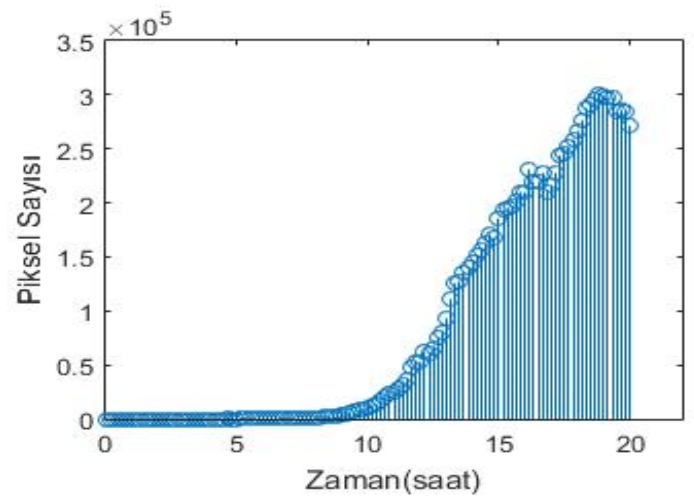

Şekil 11. Yaygı ekim yöntemiyle hazırlanan besi yeri için metalik röfle rengindeki piksel sayısının zamana göre değişsimi

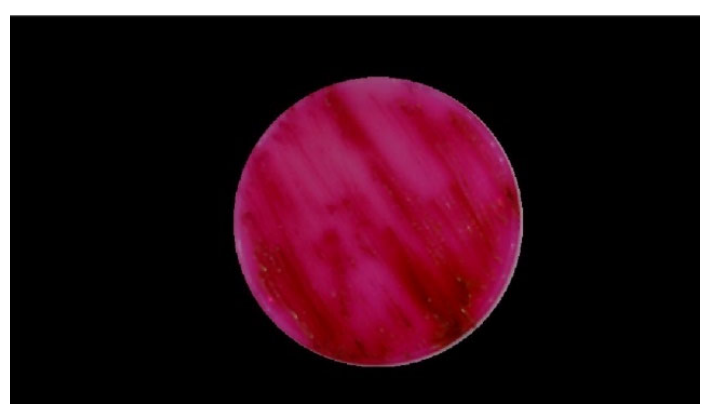

(a)

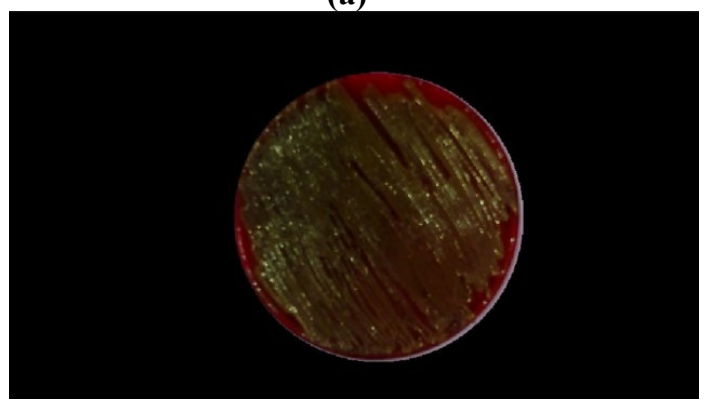

(b)

Şekil 12. Yaygı ekim yöntemiyle hazırlanan besi yerinin: (a) 9. saatteki maskelenmiş görüntüsü, (b) 24 . saatteki maskelenmiş görüntüsü

edilebildiği söylenebilmektedir. Ancak, yayg1 ekimdeki duruma benzer şekilde, bu ekim 
tekniğinde de 10. saatte çıplak gözle metalik röfle rengini tespit edebilmek mümkün değildir. 10. saatteki maskelenmiş görüntü Şekil 14 (a)'da verilmiştir. Metalik röflenin çıplak gözle net şekilde görülebildiği 24. saat görüntüsü ise Şekil 14 (b)'de verilmiştir. Bu ekim yönteminde, 24 saatin sonunda oluşan metalik röfle rengindeki piksel sayısının yaygı ekim yöntemine göre daha az olduğu da grafiklerden görülebilmektedir.

\section{SONUÇ}

Hastalık yapıcı etkisi göz önüne alındı̆̆ında $E$. coli bakterilerinin herhangi bir su kaynağına bulaştığında hızlı bir şekilde tespit edilebilmesi hayati öneme sahiptir. Günümüzde kullanılan teknikler ile bu işlem yaklaşık olarak $22 \pm 2$ saat sürmektedir. Özellikle belediyelerin şehirlere dağıtım yaptıkları su depolarında bu testler yapıldığında, sonuç alınıncaya kadar kirlenmiş sular son kullanıcının musluklarına ulaşmakta ve hastalık oluşturacak sular içilebilmektedir. Dolayısıyla suyun bakteriyolojik analizini hızlandırabilecek, aynı zamanda bunu kırsalda da kolay şekilde yapılabilir hale getirecek her türlü çalışma çok önemlidir. Bu çalışmada bakteri tespit işlemini kolay ve hızlı şekilde yapabilecek bir analiz düzeneği ve görüntü işleme tabanlı bir analiz yöntemi önerilmiştir. Düzenek ve yöntem, farklı şekilde bakteri ekilmiş besi yerleri kullanılarak test edilmiştir. Elde edilen bulgular incelendiğinde, bakteri tespit işleminin 8-10 saat sürede gerçekleştirilebileceği görülmüştür. Ayrıca her zaman inkübatör gibi uygun donanımın bulunamama ihtimali göz önünde bulundurularak, önerilen yöntem oda sıcaklığında yapılan deneylerle sınanmıştır. Deneylerin $37{ }^{\circ} \mathrm{C}^{\prime} \mathrm{de}$ ve bakteri üremesi için daha uygun nem koşullarına sahip inkübatör ortamında yapılması durumunda bakteri tespit süresinin daha da k1salacağı öngörülmektedir. Bu çalışmada elde edilen veriler derin öğrenme algoritmalarıyla birlikte kullanıldığında bakteri oluşumunu otomatik olarak tespit edebilen ve kullanıcıyı uyarabilen bir yapay zekâ algoritmasının da geliştirilebileceği düşünülmektedir. Gelecekte bu yönde çalışmalara devam edilmesi ve insan sağlığı için çok önemli olan bakteriyolojik su incelemesinin hızlı, kolay ve otomatik şekilde yapılmasını sağlayacak bir düzenek ve yöntem ortaya çıkarılması planlanmaktadır. Bu çalışmada elde edilen sonuçlar gelecekteki çalışmalar için oldukça umut verici niteliktedir.

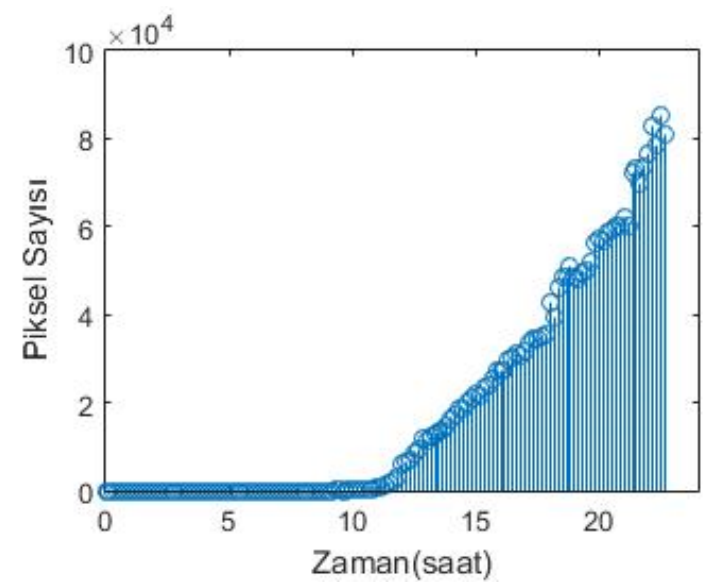

Şekil 13. Sol üst tarafına damlatma yoluyla ekim yapılan besi yeri için metalik röfle rengindeki piksel sayısının zamana göre değişimi

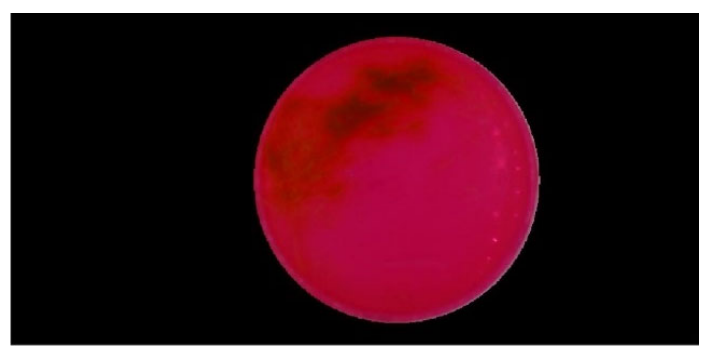

(a)

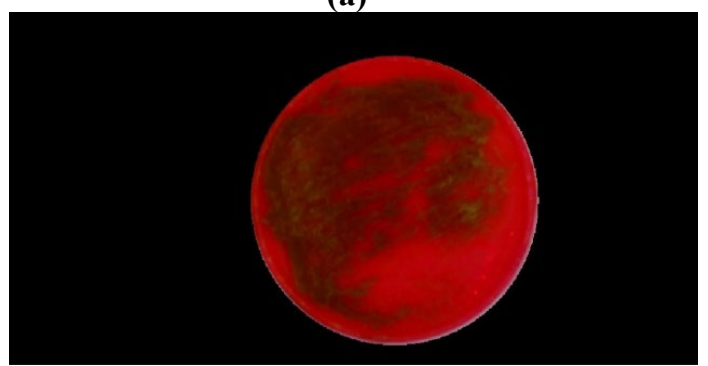

(b)

Şekil 14. Sol üst tarafa damlatma yoluyla ekim yapılan besi yerinin: (a) 10. saatteki maskelenmiş görüntüsü, (b) 24 . saatteki maskelenmiş görüntüsü 


\section{TEŞEKKÜR ve BILGGILENDIRME}

Bu çalışma tüBİTAK tarafından 1139B411701880 numaralı proje kapsamında desteklenmiştir. Yazarlar çalışma süresince sağladığı destek için TÜBİTAK'a ve Mersin Üniversitesi Çevre Mühendisliği Bölümü’nden Prof. Dr. Ali ÜNYAYAR, Aslı CON ve Özlem SANSARCI'ya teşekkür ederler.

Çalışmanın yapıldığı dönemde yazarlardan Ahmet Hilmi KALOĞLU, Emre GÜVEN, Samet DURAK ve Hakan ORBUK, Mersin Üniversitesi Elektrik Elektronik Mühendisliği Bölümü lisans son sınıf öğrencileri olup, Evren DEĞİRMENCİ projenin akademik sorumlusu, bu çalışmanın ise hem başlıca yazarı, hem de sorumlu yazarıdır.

\section{KAYNAKLAR}

1. Dedekayoğulları, H., Önal, A., 2009. Çevreİnsan Sağlığı İlişkisi Açısından $\mathrm{Su}$ ve $\mathrm{Su}$ Analizinin Önemi. İstanbul Tıp Fakültesi Dergisi, 72(2), 65-70.

2. Anonim, TS 266 Sular-İnsanî Tüketim Amaçlı Sular, Türk Standartları Enstitüsü, 2005.

3. WHO, 2013, Water Quality and Health Strategy 2013-2020.

4. Edberg, S.C., Rice, E.W., Karlin, R.J., Allen, M.J., 2000. Escherichia Coli: The Best Biological Drinking Water Indicator for Public Health Protection, J.Appl. Microbiol., 88(S1), 106-116.

5. Marrs, C.F., Zhang, L., Foxman, B., 2005. Escherichia coli Mediated Urinary Tract Infections: Are there Distinct Uropathogenic $E$. coli (UPEC) Pathotypes? FEMS Microbiol Lett, 252(2), 183-190.

6. http://www.euro.who.int/en/healthtopics/emergencies/international-healthregulations/news/news/2011/07/outbreaks-ofe.-coli-o104h4-infection-update-30 (En son görüldüğü tarih: 20.08.2019).

7. Akyar, I., 2011. Kütle Spektrometrisinin Mikrobiyolojide Kullanımı, Acıbadem Üniversitesi Sağlık Bilimleri Dergisi, 2(4), 177-183.
8. Alemdar, S., Kahraman, T., Ağaoğlu, S., Alişarlı, M., 2009. Bitlis İli İçme Sularının Bazı Mikrobiyolojik ve Fizikokimyasal Özellikleri, Ekoloji Dergisi, 19(73), 29-38.

9. Pérez Rodríguez, F., Campos, D., Ryser, E. T., Buchholz, A.L., Posada-Izquierdo, G.D., Marks, B.P., Todd, E., 2011. A Mathematical Risk Model for Escherichia coli O157:H7 Cross-contamination of Lettuce During Processing, Food Microbiology, 28(4), 694-701.

10. Prachaiyo, P., Mclandsborough, L.A., 2000. A Microscopic Method to Visualize Escherichia coli Interaction with Beef Muscle, Journal of Food Protection, 63(4), 427-433.

11. Adeyanju, G., Ishola, O., 2014. Salmonella and Escherichia coli Contamination of Poultry Meat from a Processing Plant and Retail Markets in Ibadan, Oyo State, Nigeria, SpringerPlus, 3(1), 139.

12. Xie, J., Khan, S., Shah, M., 2008. Automatic Tracking of Escherichia coli Bacteria, Medical Image Computing and Computer-Assisted Intervention-MICCAI, New York.

13. Noguera, P.S., Posthuma-Trumpie, G.A., Van Tuil, M., Van der Wal, F.J., Boer, A. De Moers, A.P.H.A., Van Amerongen, A., 2011. Carbon Nanoparticles as Detection Labels in Antibody Microarrays. Detection of Genes Encoding Virulence Factors in Shiga Toxin-Producing Escherichia coli. Analytical Chemistry, 83(22).

14. Golberg, A., Linshiz, G., Kravets, I., Stawski, N., Hillson, N.J., Yarmush, M.L., Konry, T. 2014. Cloud-Enabled Microscopy and Droplet Microfluidic Platform for Specific Detection of Escherichia coli in Water, PLOS One, 9(1).

15. Jakobs, S., Subramaniam, V., Schönle, A., Jovin, T.M., Hell, S.W., 2000. EGPF and DsRed Expressing Cultures of Escherichia coli Imaged by Confocal, Two-Photon and Fluorescence Lifetime Microscopy, FEBS Letters, 479, 131-135.

16. Baruah, S., Ortinero, C., Shipin, O.V., Dutta, J., 2011. Manganese Doped Zinc Sulfide Quantum Dots for Detection of Escherichia coli, Journal of Fluorescence, 22(1), 403-408.

17.Zeinhom, M.M.A., Wang, Y., Song, Y., Zhu, M.J., Lin, Y., Du, D., 2018. A Portable Smartphone Device For Rapid and Sensitive 
Detection of E. coli $\mathrm{O} 157: \mathrm{H} 7$ in Yoghurt and Egg, Biosensors and Bioelectronics, 99, 479-485.

18. Vadivambal, R., Jayas, D.S., 2011. Applications of Thermal Imaging in Agriculture and Food Industry - A Review, Food Bioprocess Technol, 4, 186-199.

19. Windham, R.W., Yoon, S., Ladely, S.R., Haley, J.A., Heitschmidt, J.W., Lawrence, K.C., Park, B., Narrang, N., Cray, W.C., 2013. Detection by Hyperspectral Imaging of Shiga ToxinProducing Escherichia coli Serogroups O26, O46, O103, O111, O121 and O145 on Rainbow Agar, Journal of Food Protection, 76(7), 1129-1136.

20. Siripatrawan, U., Makino, Y., Kawagoe, Y., Oshita, S., 2011. Rapid Detection of Escherichia coli Contamination in Packaged Fresh Spinach Using Hyperspectral Imaging, Talanta, 85, 276-281.

21. http://www.mikrobiyoloji.org/TR/Genel/Belge Goster.aspx?F6E10F8892433CFFA79D6F5E6C1B4 3FF2B0AD73D1B0C3DA3 (En son görüldüğü tarih: 20.08.2019).

22. Alişarlı, M., Ağaoğlu, S., Alemdar, S., 2007. Van Bölgesi İçme ve Kullanma Sularının Mikrobiyolojik Kalitesinin Halk Sağlı̆̆ Yönünden İncelenmesi, Yüzüncü Y1l Üniversitesi Veterinerlik Fakültesi Dergisi, 18(1), 66-77.

23. Kumbur, H., Erkurt, E.A., Gülçiçek, O., 2007. Mersin Üniversitesi Çiftlikköy, Yenişehir ve Tece Kampüs Sularının Mikrobiyolojik Yönden İncelenmesi, Ulusal Çevre Sempozyumu, Mersin Üniversitesi Çevre Mühendisliği Bölümü Çiftlikköy Kampüsü, Mersin.

24. Kireççi, E., Savaşçı, M., Uslu, H., 2006. Kars ve Sarıkamış Çevresindeki İçme Suyu Kaynaklarından Membran Filtrasyon Yöntemi ile Escherichia coli İzolasyonu, Atatürk Üniversitesi Veteriner Bilimleri Dergisi, 1(1-2), 29-32.

25. Duda, R.O., Hart, P.E., 1972. Use of the Hough Transformation to Detect Lines and Curves in Pictures, Communications of the ACM, 15(1), 11-15.

26. Gonzalez, R.C., Woods, R.E., 2007. Digital Image Processing Third Edition, 1, Pearson/Prentice Hall, NY.
27. Boiangiu, C.A., Simion, M., Lionte, V., Mihai, Z., 2014. Voting Based Image Binarization, the Proceedings of Journal ISOM, 8, 343-351.

28. Finlayson, G.D., Schiele, B., Crowley, J.L., 1998. Comprehensive Colour Image Normalization, European Conference on Computer Vision. Springer, Berlin, Heidelberg. 